IRA-International Journal of Management \&

Social Sciences

ISSN 2455-2267; Vol.11, Issue 02 (May 2018)

Pg. no. 91-98.

Institute of Research Advances

http://research-advances.org/index.php/RAJMSS

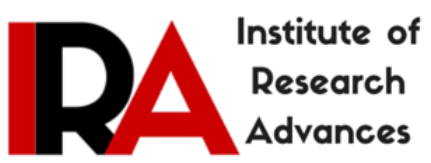

\title{
Digital Business: The Transition into New Age Dealing; Emphasizing Inputs from Cloud Computing and Big Data-An Indian Case
}

\author{
P. K. Paul ${ }^{1 \#}$, A. Bhuimali ${ }^{2}$, Kalishankar Tiwary ${ }^{3}$, P. S. Aithal ${ }^{4}$, R. Rajesh ${ }^{5}$ \\ ${ }^{1}$ Raiganj University (RGU), West Bengal, India \\ ${ }^{2}$ Vice Chancellor, Raiganj University, West Bengal, India \\ ${ }^{3}$ HoD, Mathematics \& Director-IQAC, Raiganj University, West Bengal, India \\ ${ }^{4}$ Vice Chancellor, Srinivas University, Karnataka, India \\ ${ }^{5}$ Principal, Rohini College of Engineering and Technology, TN, India
}

\#corresponding author

Type of Review: Peer Reviewed.

DOI: http://dx.doi.org/10.21013/jmss.v11.n2.p4

\begin{abstract}
Paul, P. K., Bhuimali, A., Tiwary. K., Aithal, P. S., Rajesh, R. (2018). Digital Business: The Transition into New Age Dealing; Emphasizing Inputs from Cloud Computing and Big Data-An Indian Case. IRA-International Journal of Management \& Social Sciences (ISSN 2455-2267), 11(2), 91-98. doi:http://dx.doi.org/10.21013/jmss.v11.n2.p4
\end{abstract}

(C) Institute of Research Advances.

\section{(cc)) BY-NC}

This work is licensed under a Creative Commons Attribution-Non Commercial 4.0 International License subject to proper citation to the publication source of the work.

Disclaimer: The scholarly papers as reviewed and published by the Institute of Research Advances (IRA) are the views and opinions of their respective authors and are not the views or opinions of the IRA. The IRA disclaims of any harm or loss caused due to the published content to any party.

Institute of Research Advances is an institutional publisher member of Publishers Inter Linking Association Inc. (PILA-CrossRef), USA. The institute is an institutional signatory to the Budapest Open Access Initiative, Hungary advocating the open access of scientific and scholarly knowledge. The Institute is a registered content provider under Open Access Initiative Protocol for Metadata Harvesting (OAI-PMH).

The journal is indexed \& included in WorldCat Discovery Service (USA), CrossRef Metadata Search (USA), WorldCat (USA), OCLC (USA), Open J-Gate (India), EZB (Germany) Scilit (Switzerland), Airiti (China), Bielefeld Academic Search Engine (BASE) of Bielefeld University, Germany, PKP Index of Simon Fraser University, Canada. 


\begin{abstract}
Business in today's age changing rapidly, there are many reasons for this kind of transition of business houses and corporate bodies. Moreover, people in today's age are using more online and digital means for the business and thus overall business systems are emphasize digital sources of revenue as well as digital channels. The concept of creation and dependencies of tools and technologies for financial economics systems is called Digital Economy and the growth of this leads to the development and familiarity with digital products and services among the service seekers and these ultimately are resulted in newer and competitive advantages in the digital space and system. Digital technology and its nature is also changing and has also challenged the existing business models. Here the key driving forces are included the capacity of innovation as well as the public availability of IT in different way. Digital business today is not a concept but it is about that stage of IT and Computing applications in different models viz. in marketing, ICT, social, business houses, healthcare, education and so on. Importantly these models may be seen as the convergence of technologies/ fully connected/integrated stage. In today's age business is not only seen with computing and digital means but the traditional business systems also getting benefits from the ICT and here among the emerging names, few important include cloud computing, the Internet of Things, mobile and Big Data. It is important to note that this paper emphasizes the recent applications and role of Cloud Computing and Big Data in Business with a case of India. Moreover different financial aspects have also been described and analysed.
\end{abstract}

Keywords: Business, Digital Business, ICT, Cloud and Big Data, Emerging IT, IT Applications, IT Management, Introduction India, Knowledge Economy

Digital business is the combination of business and technologies (especially IT components and its uses). Hence it is more than the technology and it about the applications of digital technologies (IT Applications) in the business in real life. Moreover, it has (Digital Business) also impact into the behavior and attitudes of the consumer across all their activities [1], [6]. Here all the team and manpower of an organization including executives, teams and people etc use Digital tools and systems into their system and affairs to improve the current systems and also ways they serve their customers, collaborator, and moreover about the operation.

Digital business is a kind of people-centric approach of using technology and supply processes to enable customers, employees, managers, etc. for the organizational promotion. Importantly, Digital Business basically employed in current age to gear up all types of business functions and thus it is responsible for the making business and ventures more updated, relevant, and profitable. Digital business increasingly connected and helps in interconnections and builds the ecosystem for the betterment of organizations and thus indirectly helps to the common people to live and work effectively. There are many stakeholders in Digital business community and here internal community responsible for driving the business is common and in this space few professionals either individually or jointly play a good role viz. CIO, CTO, Systems Manager, User Experience Designer, Business Analyst etc and here they should know the role of digital technology and also and how it is used (or to be used) by customer, employees, and other stakeholders [12], [16]. Initially the traditional components of IT viz. Networking, Web Technology, Database Technology etc had a great impact on the promotion of business houses but gradually other technologies viz. Cloud Computing, Internet of Things (IoT), Big Data Management are employed.

\title{
Objective
}

The current paper is conceptual in nature and deals with several aim and agendas in respect of Business (Digital Business) viz.-

- To learn about the basics of business and management and its different kind of forms in a simple manner.

- To know about the components of Information Technology which are useful in Business and Corporate segments.

- To learn about the emerging and sub fields of Information Technology for the creating and development of Digital Business.

- To know about the different forms and deployment models of Cloud Computing and emerging/ related areas. 
- To learn about the nature and characteristics of Digital Business in simple and general form.

- To know about the Indian Big Data market with a brief on the international market of this emerging field for the promotion of Digital Business.

- To learn about the Cloud Computing market and financial implications with reference to Indian Cloud Computing market.

- To learn about the challenges and opportunities of Cloud Computing and Big Data Market in India.

\section{Digital Business}

Digital business helps in the creation of newer business models, better and healthy customer experiences and thus internally these are to help in core business support of operations. Digital business includes both digital (here digital technologies means IT products, tools, and devices) and also Business houses and business and corporate affairs [16], [17], [18]. There are many expert opinions and views in the regard of Digital Business and among them, Thomas H. Davenport and George Westerman in Harvard Business Review [19] explained that "Digital is not just a thing that you can buy and plug into the organization. It is multi-faceted and diffuse, and doesn't just involve technology. Digital transformation is an ongoing process of changing the way you do business. It requires foundational investments in skills, projects, infrastructure, and, often, in cleaning up IT systems. It requires mixing people, machines, and business processes, with all of the messiness that entails. It also requires continuous monitoring and intervention, from the top, to ensure that both digital leaders and non-digital leaders are making good decisions about their transformation efforts."

According to Gartner, Digital Business is all about the better performance of business by the following components (also referred in Fig: 1)

- Things/ Products.

- Business and Venture

- People and Manpower

- Digital Designing

- Digital Interacting

- Digital Operating.

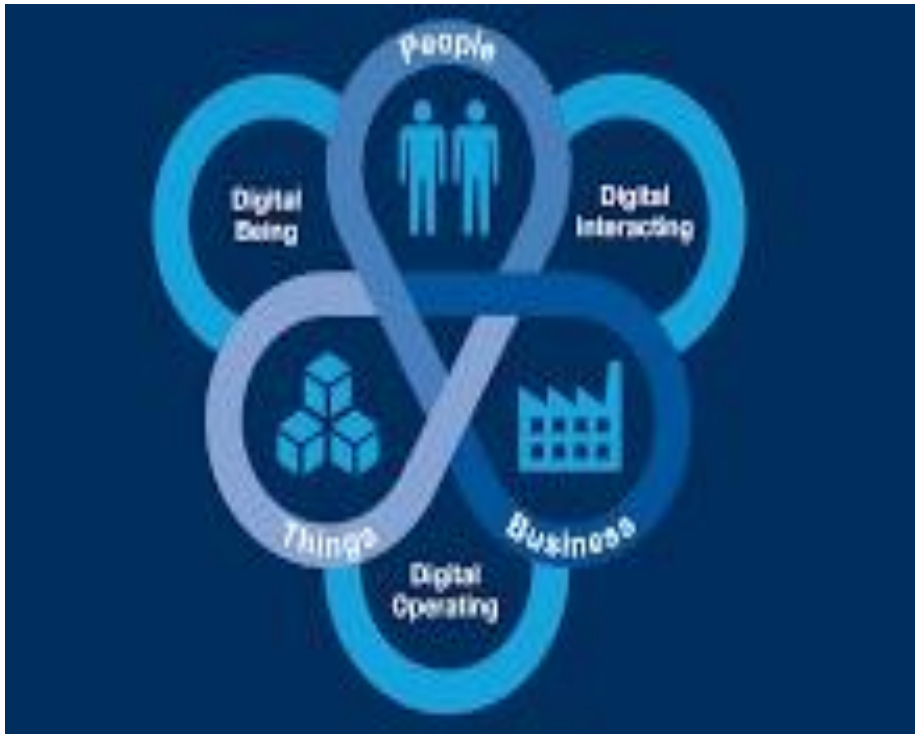

Fig: 1 Core Stakeholders in Digital Business (Source: Gartner) [13] 


\section{Features and Elements of Digital Business}

From the above literature it has already been known about the basics of Digital Business, it is about the combination of technologies and business elements. Hence the combination of Computing and Management is the core of Digital Business [13], [15]. In other words, the stakeholders of the Digital Business include (but not limited to)-

- Technologies

- Tools and Products

- Information

- People

- Business Houses

- Services

There are several views on the exact definition of digital business from the management and business expert and thus here few opinions from the industry have been depicted viz.

"Digital businesses create competitive edges based on unique combinations of digital and physical resources. They do things that others cannot and in ways that build comparative advantage."-Accenture

"Digital business is the creation of new value chains and business opportunities that traditional businesses cannot offer".-Gartner

"Digital should be seen less as a thing and more a way of doing things."-McKinsey

It is important to note that most digital businesses follows some or all of these points and views and they focus on creating new value at new frontiers and moreover they employ new media and digital technology for the growth and development drive; moreover revenue etc. Importantly Digital Business helps in performance development which are tough (and sometimes impossible) in traditional models.

It is worthy to note that the common elements of digital business may be changed accordingly based on requirement and it needs comparison against the existing business models. Though in general, following may be the core reason and facets of the Digital Business-

- The existing services need better customer experience and thus Digital businesses may be provided for the competitive advantages and reducing overhead systems and obviously in providing new value to the customers.

- The organization with better digital systems can go for healthy and best implementation and management for the digital services for the improved organizational systems. Thus digital business is especially helpful in creation of new kind of roles. Hence here good input is provided into new strategic decisions and ultimately these empower the status.

- The technologies and tools are important for better and healthy digital product designing and development and thus newer customer experience may be gathered. Ultimately this kind of digital business transition helps in digital creation of digital society and business [2], [3], [8].

\section{Technologies behind Digital Business}

Information Technology actually consists of different kind of components viz. Database Technology, Web Technology, Networking Technology, Multimedia Technology, Communication Technology etc. It is expected that within 2020 about seven billion people, businesses and also about 30 billion devices will be associated with the Internet. With Digital Business it is about the good connection of the people, businesses and transacting etc [4], [5], [16].

The creation of newer business designs is possible with solid strategies of Digital Business. The solid digital business promoted the convergence of technologies, people, business and a good sustainable business model including e-business and e-commerce.

A Digital Business and an E-Business have many differences and among these few important are included in a Digital Business that always engaged in promoting newer business and creating a smart and intelligent business 
organization irrespective of their forms. Digital business could involve in the seamless integration of digital as well physical systems that blends the boundaries of these two. An improved efficiency always comes with the Digital Business and thus it gives productiveness. Real-time business is always possible with the introduction of Digital Business [16], [17], [20], [21].

Among the emerging concepts, few important are include Cloud Computing, Internet of Things, Big Data etc with perfect and dedicated digital business models. Internet of Things (IoT) basically plays a crucial role in a digital business and Gartner defines that it is the network of physical objects that contain embedded technology to communicate and interact with their internal states or the external environment'. Hence it will help in gearing up business - whether tangible or intangible.

Digital business is about the creation of new business designs with newer digital and IT tools and for the creation of the digital world. The integration and interaction between business and things are possible with Digital Business. The scenario of business of past, present and future is noticeable and will help a lot [15], [18].

The digital business systems help in advance management to the business executives, managers and professionals, Chief Technology Officers, CIOs and technology providers and other for decision making and faster improvement as well. Hence for the initiation of Digital Business we need to think differently to help the organizations and different kind of businesses houses to do the needful.

The current business leaders are using a different kind of digital business skills, however the new roles of IT professionals in business viz. chief digital officer, CTO etc will emerge as catalyst roles, all business leaders and CIOs need changing basis and thus business professionals in this days requires healthy systems for promoting business. Business leaders need to maintain and take challenges in the digital business and here CIOs, CIOs and others have to play a good and healthy role. Both from-end and back-end technology is required for making the digital venture.

Digital business applications consist of the universe of applications of ICT and allied tools to promote business smart and making things automatically. It will allow rapid development and also new capabilities for creating a new type of venture and for competitive advantage. In today's age websites are the mirror of an organization and here billions of things, humans and businesses etc are inter-related and here this convergence also plays a good and sophisticated role for business engineering as well. It is about the integration and fulfillment of a future of people including organizational, business and all type of tangible things.

Digital technology is changing rapidly the business process and business model in different way. Technologies like Big Data Applications, Internet of Things and 3D printing etc will help in the creation of new kind of digital business processes, models and moments etc for a next generation business systems. Organizations and corporate hence employing digital tools, techniques and technologies not only help in the promotion of their shelf but also digital economy but also sustainability.

\section{Cloud Computing as a driving force}

Cloud Computing is one of the emerging names in today's Information Technology (IT) field, it is about the virtualization of IT infrastructure which includes the applications, software, hardware, platform, systems and so on. It is normally classified into three viz. Public Cloud, Private Cloud, Hybrid Cloud Computing. Public Cloud Computing normally offered and available by the third party for sharing of IT Infrastructure by the online and similar systems empowered by the internet and similar services. Private Cloud actually offered by the institute itself and housed inside for the affairs and in this, there is a limited risk. Though, combination of clouds it is also possible called Hybrid Cloud Computing. In all these areas market are booming and according to major organizations this will rise in future [4], [5], [9].

The Gartner projected that public cloud services were projected to grow $38 \%$ in 2017 (total about $\$ 1.81$ billion) as far as India is concerned. The highest growth as per Gartner may reach by the IaaS i.e. infrastructure as a service 
which was expected to grow at $49.2 \%$ in 2017 though it was expected that SaaS grow by $33 \%$ in software as a service (SaaS). It was expected by the Gartner that total $32.1 \%$ service might be geared by the PaaS service of the cloud.

According (in his word) to the Sid Nag, Research Director, Gartner "We see increased cloud growth in the infrastructure and computing services space as adoption becomes increasingly mainstream". "This has been predicted for a while, and the momentum continues to sustain in 2017 eventually plateauing through 2020 as the market further matures."

Though according to the Gartner the highest growth of the Cloud Market may reach anyhow about 4101 Millions of USD, this includes all type of cloud services in the year 2020. Though, among the cloud service highest growth may reach by the IaaS with 2028 Millions of USD. Though, PaaS may grow up to 287 Millions of USD in the year 2020. The security is a major concern in coming days and here the expected market in 2020 according to the Gartner is 281 Millions of USD. The Table: 1 is showing the expected market growth as per Gartner herewith.

Table 1. India Public Cloud Services Forecast (Millions of U.S. Dollars)

\begin{tabular}{|l|l|l|l|l|l|}
\hline & 2016 & 2017 & 2018 & 2019 & 2020 \\
\hline Cloud Business Process Services (BPaaS) & 88 & 113 & 145 & 186 & 236 \\
\hline Cloud Application Services (SaaS) & 396 & 527 & 675 & 824 & 1006 \\
\hline Cloud Application Infrastructure Services (PaaS) & 107 & 141 & 182 & 230 & 287 \\
\hline Cloud System Infrastructure Services (IaaS) & 486 & 725 & 1051 & 1473 & 2028 \\
\hline Cloud Management and Security Services & 116 & 152 & 190 & 234 & 281 \\
\hline Cloud Advertising & 123 & 158 & 189 & 223 & 266 \\
\hline Total & 1,316 & 1,817 & 2,432 & 3,169 & 4,104 \\
\hline
\end{tabular}

\section{Big Data Market in India}

Big Data is actually managing the large number and complex data in the current scenario. It is a fact that day by day this is increasing and thus for managing the concept of Big Data is emerged and added few other concerns also. Combing all these is called Big Data Analytics and Big Data Management [6], [10], [11].

Big data is applicable now everywhere and it is predicted by the major survey based organizations that market will grow at Compound Annual Growth Rate (CAGR) of 18\% which is comparatively high. The year 2015 is considered as the base year and it is expected that Big Data market will fly and spans from 2016 to 2021.

There are huge demands for analyzing big data professionals due to a large number of data and out of these important concerns are increasing number of mobile apps and devices etc and thus big data services and solutions is increasing across many organizations [14], [15]. There are many services offered by the Big Data agencies and here software agencies also play a good role. Among the allied markets, few important include big data analytics, visualization, data discovery and big data management software including system integration. Though many firms offer consultancy and managed services also. According to the Big Data Market, it is segmented into five major regions viz. -

- $\quad$ Europe, North America

- Middle East

- Africa and Latin America

- Asia-Pacific.

The ecosystem of big data normally consists of different kind of big data solutions and demand based service providers. Among the big companies, few important are include-

- Microsoft Corporation 
- International Business Machines (IBM) Corporation.

- Hewlett-Packard Enterprises.

- Oracle Corporation.

- SAS Institute.

- SAP SE.

There are other organizations and companies are engaged in this field and internationally popular viz. Dell Incorporation, Amazon Web Services, Splunk, Teradata, Hitachi, Gooddata, Palantir, Mongo DB and Cloudera etc. Importantly most of these organizations and companies are offered effective distribution and solutions in the big data market. Though, solutions for the organizations such as government and defense, Banking and Financial services, manufacturing and healthcare and life sciences etc is rising day by day. Few other services such as transportation, retail, consumer goods, academia, and research also these days governed by emerging technologies and here Big Data is playing a lead role [11], [15].

Big data is today a good player in the global market since the birth of the Internet and here Big Data Analytics etc have played a lead role. These days organizations need a large number of data, thus a competitive pressure is noticeable various new technologies and among these Big Data play a lead role. Organizations are these days that's why providing importance to the data culture including better sense in collection, selection, organization, processing, management, and dissemination. Hence a whole Big Data is playing a good role.

Many organizations are doing well in Data Management market and here Big Data is a major one for creating opportunities powered by various analytics with productivity and profitability. According to National Association of Software and Services, India's big data analytics market will enhance rapidly by 2025 and these may be reaching as high as $\$ 16$ billion at present it is about $\$ 2$ billion. India at present is world's top 10 big data market (according to the NASSCOM) and moreover, it is expected that it will be world top 3 three in the world soon [5], [14].

The VP of NASSCOM, K.S. Viswanathan predicted the sector growing at a compounded annual growth rate (CAGR) of $26 \%$ in the next five years. He said the sector possessed a huge potential to grow and by 2025, India should have $32 \%$ share of the global big data market. It has noted that NASSCOM has agreed to the leadership, skills development, platforms etc for solid and healthy big data applications and management.

According to NASSCOM, there are about 600 big data and analytics firms in India and out of these 400 are startups. It has noted that in 2015 alone total 100 companies have been added. The analytical firms in India are also emerging as a hub for the field of analytics solutions all over the world. The big data industry is growing rapidly and this is due to the increase in the demand for cloud-based solutions required by the major industries and organizations viz. Banking and Finance, healthcare, telecom, and retail. There are tremendous growths in big data segment, several data analytics areas and thus massive manpower is working and expecting to in coming years.

Analytics is getting a major boost in the Data Management age and report states that in last few years due to the global recession and after that among the emerging services important is Big Data due to emerging services and verticals.

It is important to note that BPO industry is also gaining benefits from the big data but Indian BPO industry is dealing with 37 percent of total global sourcing BPO revenues

\section{Conclusion}

The big data market is employed by government bodies and agencies in recent past viz. Aadhar and UPI etc. India's largest Auditor CAG (Comptroller and Auditor General of India) already has started a project called 'Big Data Management Policy' for planning and implementing big data applications. CAG is interested in enhancing state and union governments for the development and also capacity building in the accounts department and similar bodies. The NITI Aayog is another body in India doing several affairs in big data implementation in India, it is planning to incorporate skills and also developing platforms for its applicability, storage, security, and scope etc [14], [15]. 
Moreover, it is helpful in promoting general profit making bodies and companies and profit making corporations. Importantly promoting Digital Business and similar venture will also gain by this kind of applications and technologies viz. Big Data Technologies, Cloud Computing, and so on. Moreover, to become a true Digital India similar technologies are also very important and growing rapidly.

\section{References}

[1] Aithal, P. S., (2015). Concept of Ideal Business \& Its Realization Using E-Business Model. International Journal of Science and Research (IJSR), 4(3), 1267 - 1274, DOI : http://doi.org/10.5281/zenodo.61648.

[2] Aithal, P. S. (2015). Mobile Business as an Optimum Model for Ideal Business. International Journal of Management, IT and Engineering (IJMIE), 5(7), 146-159. DOI : http://doi.org/10.5281/zenodo.163880.

[3] Altbach, P. G. (1993). The dilemma of change in Indian higher education. Higher Education, 26(1), 3-20.

[4] Chen, H., Chiang, R. H., \& Storey, V. C. (2012). Business intelligence and analytics: from big data to big impact. MIS quarterly, 1165-1188.

[5] Davenport, T. H., \& Patil, D. J. (2012). Data scientist. Harvard business review, 90(10), 70-76.

[6] Dumbill, E., Liddy, E. D., Stanton, J., Mueller, K., \& Farnham, S. (2013). Educating the next generation of data scientists. Big Data, 1(1), 21-27.

[7] Lyon, L., \& Brenner, A. (2015). Bridging the data talent gap: Positioning the iSchool as an agent for change. International journal of digital curation, $10(1)$.

[8] Paul, P. K., \& Dey, J. L. (2017, April). Data Science Vis-à-Vis efficient healthcare and medical systems: A technomanagerial perspective. In Power and Advanced Computing Technologies (i-PACT), 2017 Innovations in (pp. 1-8). IEEE.

[9] Paul, P. K., \& Ghose, M. K. (2018). A Novel Educational Proposal and Strategies Toward Promoting Cloud Computing, Big Data, and Human-Computer Interaction in Engineering Colleges and Universities. In Advances in Smart Grid and Renewable Energy (pp. 93-102)

[10] Provost, F., \& Fawcett, T. (2013). Data science and its relationship to big data and data-driven decision making. Big data, 1(1), 51-59.

[11] Song, I. Y., \& Zhu, Y. (2016). Big data and data science: what should we teach?. Expert Systems, 33(4), 364-373.

[12] Tang, R., \& Sae-Lim, W. (2016). Data science programs in US higher education: An exploratory content analysis of program description, curriculum structure, and course focus. Education for Information, 32(3), 269-290.

[13] Thomas H. Davenport and George Westerman (2018). Why So Many High-Profile Digital Transformations Fail . Harvard Business Review, March 09, 2018, https://hbr.org/2018/03/why-so-many-high-profile-digital-transformationsfail.

[14] Varvel Jr, V. E., Bammerlin, E. J., \& Palmer, C. L. (2012, February). Education for data professionals: A study of current courses and programs. In Proceedings of the 2012 iConference (pp. 527-529). ACM.

[15] https://www.forbes.com/sites/gartnergroup/2014/05/07/digital-business-is-everyones-business/\#58b29a317f82

[16] https://www.gartner.com/newsroom/id/3592917

[17] https://economictimes.indiatimes.com/tech/ites/big-data-analytics-to-become-16-billion-industry-by2025/articleshow/59410695.cms

[18] https://www.allerin.com/blog/growth-of-big-data-industry-in-india

[19] https://www.liferay.com/resources/l?title=digital-business

[20] https://www.i-scoop.eu/digital-business/

[21] https://digitalbusinessblog.wordpress.com/tag/digital-business/ 